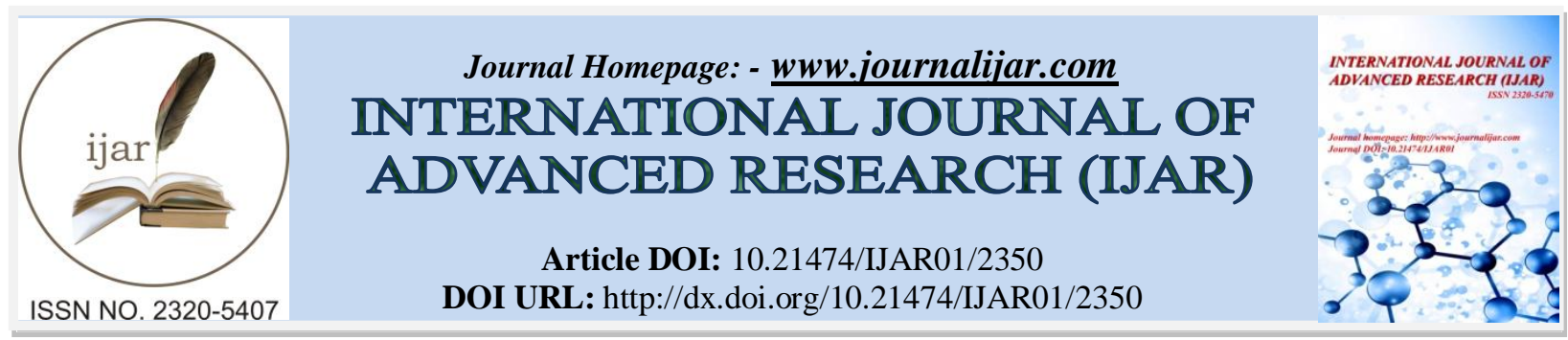

RESEARCH ARTICLE

\title{
EVALUATION OF MORPHOLOGICAL AND CYTOLOGICAL VARIATIONS INDUCED BY ETHYL METHANE SULFONATE IN CAPSICUM ANNUUM L.
}

\author{
Rajender Vadluri ${ }^{1,2 *}$, Murali Krishna Thupurani ${ }^{2}$, Phanikanth Jogam ${ }^{1}$ and Sadanandam Abbagani ${ }^{1}$. \\ 1. Department of Biotechnology, Kakatiya University, Warangal Urban, Telangana. 506009- India \\ 2. Department of Biotechnology, Chaitanya Postgraduate College (Autonomous), Kishanpura, Hanamkonda, \\ Warangal Urban, Telangana 506001-India
}

\section{Manuscript Info}

\section{Manuscript History}

Received: 30 September 2016

Final Accepted: 30 October 2016

Published: November 2016

\section{Key words:-}

Seed germination, Plant height, Number of fruits per plant, Fruit length, Number of branches, Number of leaves.

\section{Abstract}

Capsicum genus being the family of Solanaceae comprises of approximately 20 species gained immense momentum towards the genetic mutational growing at tropical and subtropical regions of the World. The present research work was framed out to evaluate the morphological and cytological variations in Chilli plant. During these studies we have screened various parameters such as, seed germination, plant height, number of fruits per plant, fruit length, number of branches, number of leaves etc,. Using single concentration of EMS $(0.1 \%)$ the seeds are treated at various time periods viz., 6,12 , $24 \mathrm{hrs}$. The healthy seed germination and overall morphological and cytological variations were observed with seeds treated for 6hrs time period. The results are compared with healthy control plant. According to our results, every parameter that we have tested exhibited grater variations in $6 \mathrm{hrs}$ treated plants compared with that from 12 and 24 hrs and control plants.

Copy Right, IJAR, 2016,. All rights reserved.

\section{Introduction}

Capsicum genus being the family of Solanaceae comprises of approximately 20 species gained immense momentum towards the genetic mutational growing at tropical and subtropical regions of the World (Basu and De, 2003).

Mutation breeding is a method of inducing mutations at loci control economically important traits and/or eliminates undesirable genes from elite breeding lines (Lippert et al., 1964). These may arise spontaneously or they may be induced using radioactive or chemical mutagen. Chemical mutagenic agents are commonly used to cause mutations in plants. Among the chemical mutagens, EMS induces vastly higher proportion of point mutations by loss of complete chromosome or its segment (Minocha \& Arnason, 1962; Hajra, 1979). It has been reported that EMS is highly potential to cause mutations in plants leads to produce plants with different and new characteristics such as early flowering in spring rape, male sterility in wheat, herbicide tolerance in soybean (Thurling and Depittayanan 1992; Sebastian et al., 1989; Maan \& Williams, 1984).

The present investigation was under taken to induce viable mutations in capsicum annum, and evaluate the morphological and cytological variations in that caused by the EMS.

Corresponding Author: Rajender Vadluri.

Address:- Department of Biotechnology, Kakatiya University, Warangal Urban, Telangana. 506009.

India. 


\section{Material and Methods:-}

Plant material and treatments applied:-

Seeds of Capsicum annuum L.of various varieties were subjected to different treatment levels with ethyl methane sulfonate $(0.1 \%$ EMS $)$. Treatment with EMS carried out at varied treatment time periods.

Amount of 5g seeds approximately 800-1000 were soaked in distilled water for 12-16hrs at room temperature and dried on filter paper. All seeds were uniformly treated with freshly prepared EMS solution for about 6, 12 and 24hrs. Seeds are rinsed thoroughly with distilled water, air-dried and transferred to pots for seed germination and subsequent mutagenic studies.

\section{Seed germination:-}

Plants were cultivated on a well-prepared growth media using farmyard manure, soil and sand with a ratio of 1:1:1 respectively. Approximately, 100 seeds of each treatment as well as control were sown in four separate pots (three for treated seeds and one for untreated seeds). These pots were irrigated well in spraying manner. Plants were irrigated on alternate days with $5 \mathrm{~g}$ of the mixture of Urea and Potash in the ratio of 1:1 up to two months. To avoid aphids, plants were sprayed twice with $0.2 \%$ solution of Monitor (insecticide) at 30 and 40 days stage. Plants were irrigated on alternate days with $5 \mathrm{~g}$ of the mixture of Urea and Potash in the ratio of 1:1 up to two months. To avoid aphids, plants were sprayed twice with $0.2 \%$ solution of Monitor (insecticide) at 30 and 40 days stage.

\section{Parameters studied:-}

In the current investigation we have studied various parameters in treated and untreated plants. Initially, all the plants were self fertilized in first generation $\left(\mathrm{M}_{1}\right)$ and were observed routinely for any sort of physical or genetical changes in second generation in them. Morphological traits such as seed germination, chlorophyll mutants, days taken to flowering, plant height, number of branches, number of leaves, days taken to fruiting, number of fruits.

\section{Cytogenetical preparations for mitotic abnormal studies in $M_{1}$ generation:-}

For the cytogenetical analysis, root meristems of chilli $(2 \mathrm{n}=24)$ were used. The chilli root tips about $3 \mathrm{~cm}$ in length were excised, fixed in glacial acetic acid: alcohol (1:3) solution for $48 \mathrm{hr}$. Then root tip squashes were made by using iron alum, haematoxylin squash technique. Cell divisions and cytogenetical abnormalities were observed and photographed under a Nikon image capturing system. The various types of cells with normal and abnormal chromosomal behavior at various stages were observed and counted.

\section{Cytological preparations for meiotic abnormal chromosomal studies in selected plants:-}

For meiotic studies young flower buds from 30-40 Morphologically selected from $\mathrm{M}_{2}$ plants were kept in a freshly prepared fixative solution containing glacial acetic acid and absolute alcohol (1:3) for $24 \mathrm{~h}$. flower buds are washed and then preserved in $70 \%$ alcohol at $4^{\circ} \mathrm{C}$. Squashing was done in $2 \%$ acetocarmine and the slides were made permanent by dehydration in butyl alcohol series followed by mounting on Canada balsam. Pollen sterility was assessed by staining pollen in $2 \%$ acetocarmine where, stained pollen grains with regular outline were considered as fertile.

\section{Statistical Analysis of Data:-}

Statistical analyses were performed using one-way ANOVA using NPRC software package at 0.05 and 0.01 levels.

\section{Result and Discussion:-}

\section{Seed germination:-}

Germination initiation was observed from $7^{\text {th }}$ day of inoculation. The healthy germination was noticed after 14 days. After passing 25-30 days the seedlings were (4-leaf stage) were shifted to new pots and as well in the field (Department of Biotechnology Kakatiya University).

Among treated seeds maximum germination percentage was observed in $6 \mathrm{hrs}$ of treatment seeds with $68 \%$. The seeds treated with 12 and $24 \mathrm{hrs}$ showed low germination percentage 56 and 48 respectively. In case of control, germination percentage was $52 \%$. EMS is a toxic compound and its treatment has an adverse effect on seed germination. Increase in treatment time with EMS resulted in gradual decrease in percentage germination of seedlings. 


\section{Chlorophyll mutants:-}

Mutagenic effectiveness reflects rate of mutation in relation to mutagenic dose, whereas, mutagenic efficiency is the mutagenic rate in relation to leathlity or biological injury. Leathlity based on germination, increased with EMS treatment time. Mutagenesis at $24 \mathrm{hrs}$ time was found high cytotoxic on the chlorophyll mutations comparing to other treatments. $6 \mathrm{hr}$ treatment was resulted low levels of changes in chlorophyll mutations. During these studies, we observed that the increased treatment time with EMS leads to high level of chlorophyll mutations (The results are presented in table 1.1).

Frequency and spectrum of chlorophyll mutations were observed to be time dependent of EMS treatment. In Accordance to the results obtained (Table 1.1) the frequency of chlorophyll mutation was directly proportional to the duration of EMS treatment (Table 1.1).

\section{Plant height:-}

Mutants were characterized on morphological basis. Overall 9 mutants were isolated. Four (6P7, 6P18, 6P39, 6P46) from 6hrs EMS treated plants, Three (12P2, 12P17, 12P36) from 12hrs and Two from 24hrs (24P41, 24P86). Individual mutants and the changes observed are represented in table 1.0 and 1.1. The morphological mutants isolated were categorized as tall, dwarf and of normal height.

Among the individual mutants, 6P18 mutant was found to be highest in height with $128 \mathrm{~cm}$. 6P7 noticed (Fig 1.0 and 1.1) second largest height with $121 \mathrm{~cm}$. Following this 12P41 and 12P17 showed moderate height with 98 and $72 \mathrm{~cm}$ respectively (Fig Fig 1.0 and 1.1). During our studies, we observed that mutants 6P46 and 24P86 were exhibited dwarf characters (Fig 1.0 and 1.1) with less height 43 and $41 \mathrm{~cm}$ respectively. While in control height ranged from $65-72 \mathrm{~cm}$.
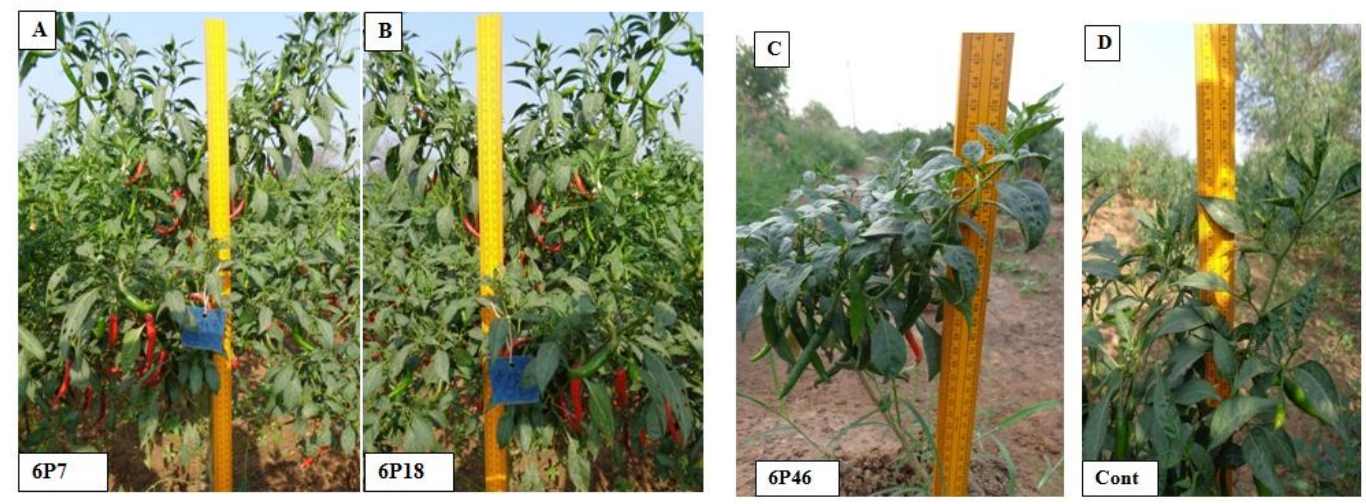

Fig. 1.0 A\&B- Plants $(6 \mathrm{P} 7,6 \mathrm{P} 18)$ showing the maximum height $(121 \mathrm{~cm}, 128 \mathrm{~cm})$ in treated with $0.1 \%$ EMS for 6 hrs. C-plant (6P46) with short height - dwarf $(43 \mathrm{~cm})$. D- Control plant $(69 \mathrm{~cm})$
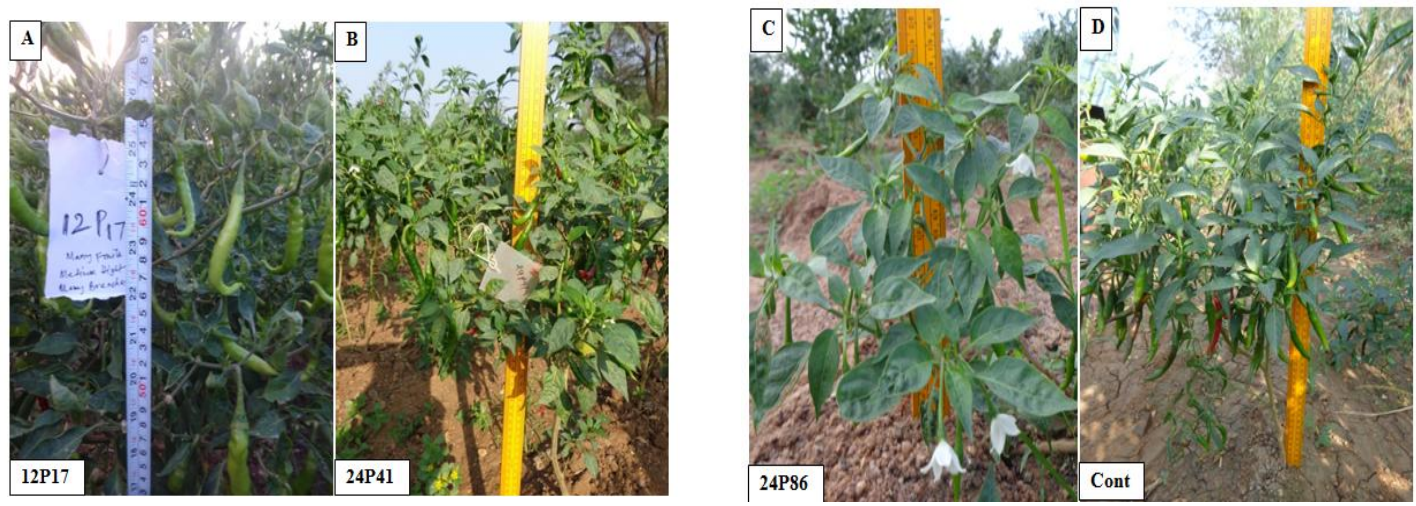

Fig. 1.1 A\&B- Plants showing the maximum height $(72 \mathrm{~cm}, 98 \mathrm{~cm})$ in treated with $0.1 \%$ EMS for 12 \& $24 \mathrm{hrs}$. Cplant with short height - dwarf $(41 \mathrm{~cm})$. D- Control plant $(68 \mathrm{~cm})$ 
Out of these 9 tall mutants, 4 were fertile and late maturing (mutant 6P18 time taken to maturity was 130 days, mutant $6 \mathrm{P} 7$ time taken to maturity was 123 days, mutant $6 \mathrm{P} 39$ time taken to maturity was 121 days, mutant $6 \mathrm{P} 46$ time taken to maturity was 118 days) while in controls time taken to maturity ranged from 92-105 days.

Some of these tall mutants such as $6 \mathrm{P} 7,6 \mathrm{P} 18,12 \mathrm{P} 36$ showed spinach like leaves These types of mutants with variable leaves were also reported earlier in Capsicum anпиит L. cultivar Keystone Resistant Giant no 3 (Alcantara et al., 1996). Leaf variegation is a common mutation which can be either a nuclear or cytoplasmic mutation EMS may have a high specificity for mitochondrial and plastid genomes (Miller et al., 1984).

Table 1.0 Individual mutants and the changes observed

\begin{tabular}{|c|l|}
\hline Plant & \multicolumn{1}{|c|}{ Morphological changes } \\
\hline 6P7 & Tall, late maturing, prolific with more number of leaves and six petal flower \\
\hline 6P18 & Tall, late maturing, prolific with more number of leaves and branches, flower smaller in size. \\
\hline 6P39 & Tall, late maturing with more number of leaves and branches, sterile flower buds. \\
\hline 6P46 & Dwarf, fertile, more number of leaves, 7 petals. \\
\hline 12P2 & Early maturing, more number of leaves, different shape of leaves, 7 petals. \\
\hline 12P17 & $\begin{array}{l}\text { Late maturing with more number of leaves and different branching pattern, prolific, petaloid } \\
\text { flower buds }\end{array}$ \\
\hline 12P36 & $\begin{array}{l}\text { Tall, more number of leaves, originally stem was divided into two branches of equal size each } \\
\text { was acting as main stem. }\end{array}$ \\
\hline $24 \mathrm{P} 41$ & More number of leaves, more number of branches, bushy habit, prolific with 7 petal flower \\
\hline $24 \mathrm{P} 86$ & $\begin{array}{l}\text { Tall, more number of leaves, originally stem was divided into two branches of equal size each } \\
\text { was acting as main stem. }\end{array}$ \\
\hline
\end{tabular}

6, 12 and 24 indicates the treatment time period and $\mathrm{P}$ indicates the term for plant and the number followed by this indicates allotted number for plant identification.

\section{Number of branches:-}

In the study we observed that there was more variation in the number of branches of the treated plants compared with control plants. The maximum variation in the number of branches was observed in plants subjected to EMS treatment for $6 \mathrm{hrs}$. The highest number of branches generated from the mutant plant 6P46. The average branches were noticed from mutant plants $6 \mathrm{P} 18,12 \mathrm{P} 17$. The results shown in standard error of the mean and are presented in table 1.1

There was more variation in the days taken to flowering of the treated plants as compare with control plants. Maximum variants were observed in plants treated with $24 \mathrm{hrs}$. (106.6 \pm 0.33$)$ and minimum was observed in plants treated for $6 \mathrm{hrs} 96.88 \pm 0.43$. In case of control group average days taken to flowering were $101.3 \pm 0.21$. The results are shown in table 1.1 .

\section{Flower mutations:-}

All these mutants had flowers with 5-lobed calyx and corolla, except from mutant 6P7 where flower had 6 petals and 24P41 and 6P46 are with 7 petals (Fig 1.2) which are compared with control plants that exhibit only 5 petals (Fig 1.2). Our studies are correlated with work carried out by Nyla Jabeen and Bushra Mirza (2004) where they also reported the follower mutations with reference to change in number of petals, sepals and ovules than normal in C. annuum $\mathrm{L}$. 

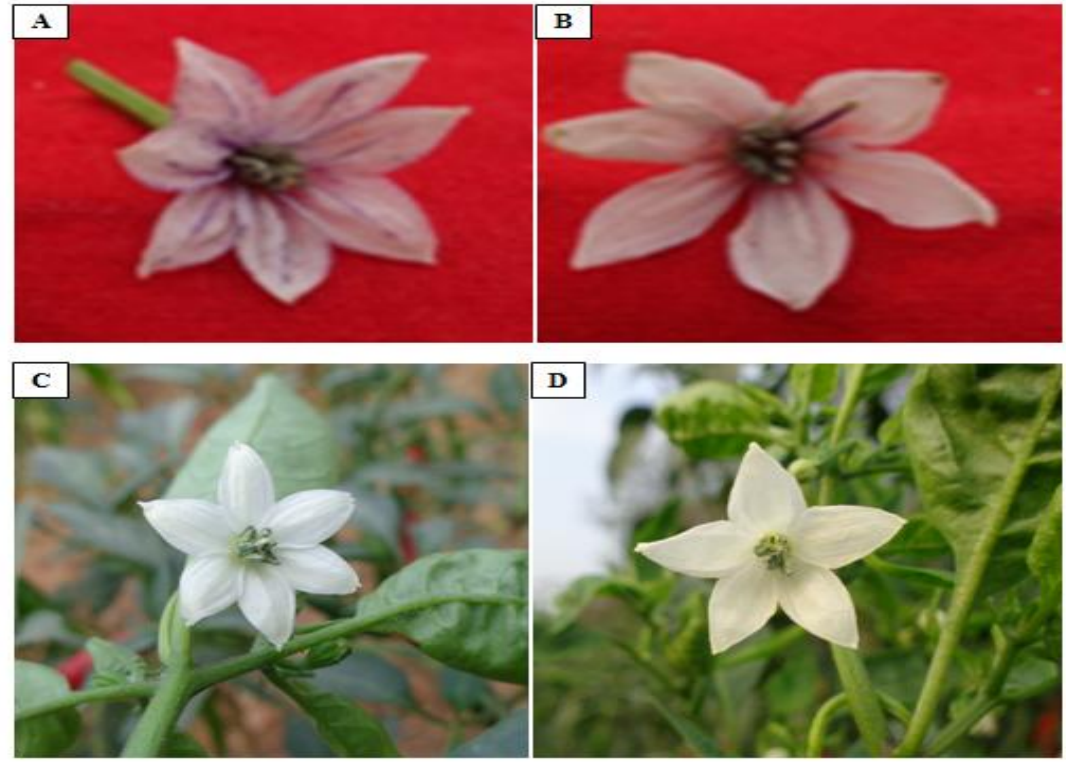

Fig. 1.2 A - flower mutant showing 7 petals, B \& C are showing 6 petals in mutant flowers, D- control flower with 5 petals.

In other tall mutants treated with 6hrs 6P39 exhibited sterile characteristics comparing to control were no plants were observed as sterile.. 12P17 mutant which was treated for $12 \mathrm{hr}$ resulted in the modification of anthers (2-4) to petaloid structures (male sterile plants).

These types of plants were recorded in treated populations only and were not observed in control plants. This is most probable because of mutations in any one or more than one genes involved in flowering and subsequently fruit development. It has been reported that there are number of genes like Leafy and Ap1 involved in flowering have been isolated from model plants like Arabidopsis and Tomato (Leandro et al., 2001). Further studies would reveal whether these genes mutated in these lines are comparable with the reported genes or not. However such lines can be very helpful to understand the mechanism of flowering and fruit development and have been used to study genes involved in crop maturation (Odeigah et al., 1996).

\section{Number of fruits:-}

Table 1.1 represents the number of fruits of all treated and untreated plants was counted. It was found that variation was more in the number of fruits of the treated plants compared to control plants. Maximum number of fruits observed in plants treated for $6 \mathrm{hrs}(120.36 \pm 0.34)$ and minimum number of fruits found at plants treated for $24 \mathrm{hrs}$ (56.98 \pm 0.4 ). In case of control the average of number of fruits are $72.4 \pm 0.8$ (Fig 1.3).

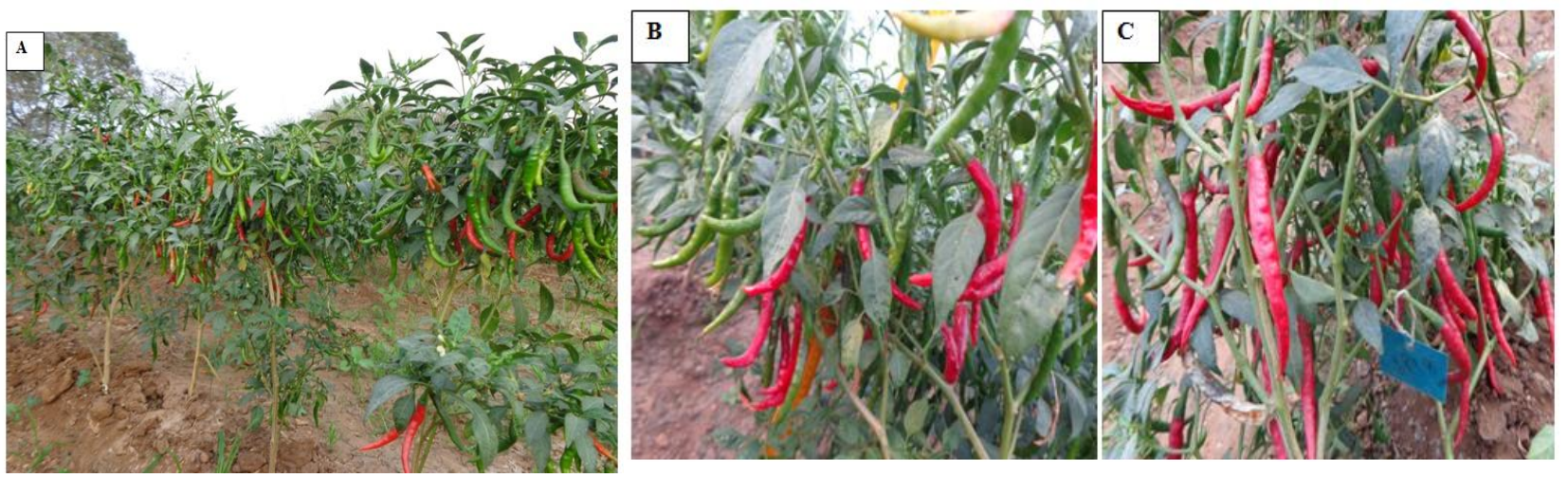

Fig . 1.3 A- maximum no of fruits observed (mean no. of fruits 120.36 \pm 0.34 ) in $0.1 \%$ EMS for 6 hrs treated plants. The observed variation in the treated population was more than that in the control population. This is the expected result because the control plants are suppose to be genetically similar and any kind of difference observed in the 
control plants is only due to environment. The results of the present study suggest that particular treatment time of the EMS below the toxic level (24hrs) can be used to increase in the genetic variability in Capsicum annuиm $\mathrm{L}$.

\section{Length of the fruit:-}

In accordance to our studies we noticed that the fruit size was found high in the plants treated with $12 \mathrm{hrs}$ compared with other treatment timings (Table 1.1). Plants treated for $12 \mathrm{hrs}$ were probably undergone high genetic variation especially that enhances the pod length and size which subsequently resulted in the increase in length of fruits (Fig 1.4).
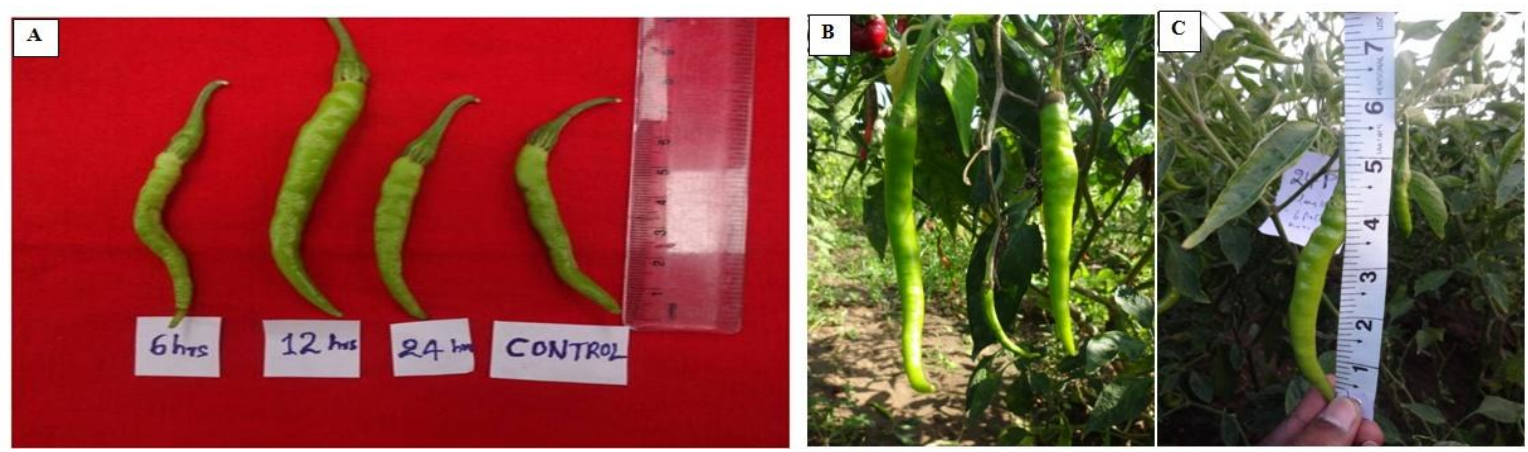

Fig. 1.4 A- Variations in length of the pods, found maximum length in $12 \mathrm{hrs}$ EMS treated plants. B- Showing the max. Length of the fruit in $12 \mathrm{hrs}, \mathrm{C}$ - control fruit with medium length.

Number of seeds per fruit:-

Number of seeds per fruit was found in high in all the fruits collected from the plants treated at different time periods with $0.1 \%$ EMS. Among the treatment timings 12 and $24 \mathrm{hrs}$ produced less number of seeds comparing to the 6hrs treatment. The results are shown in table 1.1.

Table 1.1 Mean performance of Capsicum annuum $\mathrm{L}$. in relation to different treatment times of EMS.

\begin{tabular}{|c|c|c|c|c|c|c|c|c|}
\hline $\begin{array}{c}\text { Treatment } \\
\text { Time }\end{array}$ & $\begin{array}{c}\text { Chlorophyll } \\
\text { \% }\end{array}$ & $\begin{array}{c}\text { Plant } \\
\text { Height }\end{array}$ & $\begin{array}{c}\text { No. of } \\
\text { Branches }\end{array}$ & $\begin{array}{c}\text { Day to } \\
\text { Flowering }\end{array}$ & $\begin{array}{c}\text { Flower } \\
\text { mutations }\end{array}$ & $\begin{array}{c}\text { No. of } \\
\text { fruits/plant }\end{array}$ & $\begin{array}{c}\text { Length } \\
\text { of fruit }\end{array}$ & $\begin{array}{c}\text { No of } \\
\text { seeds/fruits }\end{array}$ \\
\hline $\mathbf{6}$ & 2.5 & 130.60 & 68.24 & 98.88 & 10.09 & 120.36 & 7.2 & 70.52 \\
& & \pm & \pm & \pm & & \pm & \pm & \pm \\
& & 0.43 & 0.22 & 0.43 & & 0.34 & 0.20 & 0.10 \\
\hline $\mathbf{1 2}$ & 2.9 & 86.76 & 53.30 & 97.77 & 12.06 & 110.90 & 11.8 & 64.56 \\
& & \pm & \pm & \pm & & \pm & \pm & \pm \\
& & 0.20 & 0.34 & 0.32 & & 0.12 & 0.21 & 0.22 \\
\hline $\mathbf{2 4}$ & 4.7 & 104.20 & 23.33 & 106.6 & 8.09 & 56.98 & 6.2 & 63.02 \\
& & \pm & \pm & \pm & & \pm & \pm & \pm \\
& & 0.13 & 0.11 & 0.03 & & 0.11 & 0.15 & 0.13 \\
\hline Control & ---- & 102.00 & 25.50 & 101.3 & ---- & 72.4 & 6.8 & 70.40 \\
& & \pm & \pm & \pm & & \pm & \pm & \pm \\
& & 0.44 & 0.25 & 0.21 & & 0.08 & 0.11 & 0.99 \\
\hline
\end{tabular}

Cytological preparations for mitotic abnormal chromosomal studies in selected plants

The data showed a significant increase in the percentage of prophase cells $27.7 \%$ with using $12 \mathrm{hrs} \mathrm{treatment} \mathrm{times.}$ All the concentrations were capable of inducing various types of chromosomal abnormalities in almost all the stages of mitosis. Sticky chromosomes, precocious movements, bridges, micronucleus, laggards and anaphase with polar deviation were the most common abnormalities recorded with the use of EMS in metaphase and anaphase. The percentages of chromosomal abnormalities in different mitotic stages were significantly higher than that of the control and calculated on mitotic index, frequency of phases and percentage of abnormalities in mitosis. 
Table 1.2 Effects of EMS on mitotic index, frequency of mitotic phases and percentage of abnormalities in chilli root tip cells.

\begin{tabular}{|l|l|l|l|l|l|l|l|l|}
\hline $\begin{array}{c}\text { Treatment } \\
\text { Time. } \\
\mathbf{E M S} \\
\mathbf{1 0 m M})\end{array}$ & $\begin{array}{c}\text { Total cells } \\
\text { divided }\end{array}$ & $\begin{array}{c}\text { Total } \\
\text { abnormal } \\
\text { cells }\end{array}$ & $\begin{array}{c}\text { Abnormal } \\
\text { cells } \mathbf{( \% )}\end{array}$ & $\begin{array}{c}\text { Mitotic } \\
\text { index }\end{array}$ & $\begin{array}{c}\text { Prophase } \\
\text { No. \% }\end{array}$ & $\begin{array}{l}\text { Metaphase } \\
\text { No. \% }\end{array}$ & $\begin{array}{c}\text { Anaphase } \\
\mathbf{\&} \\
\text { Telophase } \\
\text { No. \% }\end{array}$ \\
\hline Control & 507 & 20 & 3.9 & 11.1 & 81 & 15.9 & 16332.1 & 26357.8 \\
\hline $6 \mathrm{hrs}$ & 739 & 82 & 11.1 & 16.6 & 17223.3 & 18725.3 & 38051.4 \\
\hline $12 \mathrm{hrs}$ & 710 & 85 & 11.9 & 15.6 & 19727.7 & 19928.0 & 31444.2 \\
\hline $24 \mathrm{hrs}$ & 813 & 146 & 17.9 & 18.0 & 18622.9 & 20024.6 & 42752.5 \\
\hline
\end{tabular}

In this study seeds of Capsicum annuum L. treated with $0.1 \%$ EMS for 6, 12 and 24hrs. In the laboratory seed germination test, it was observed that increase in EMS treatment time had adverse effect on seed germination. Similar results have been reported earlier (Alcantara et al., 1996). In that study seeds of Capsicum annuum L. were treated with 0.5, 1.0 and $1.5 \%$ EMS and exposed for 3, 6 and 9hrs. In the $\mathrm{M}_{1}$ generation, seeds treated with EMS for $24 \mathrm{hrs}$ had the lowest germination percentage (48\%) among all treatments. Although in this report at highest treatment time with EMS seeds had the lowest germination percentage but was still much higher than observed in our investigation. In our study when these treated seeds were planted in the field, at maximum concentration have longest exposure i.e, $24 \mathrm{hrs}$ no viable seedlings were observed. While in another report the seeds of Capsicum апnиит L. treated with 3 concentrations $(0.5,1.0$ and 5\%) for 3 time durations for 3, 6 and 9 hrs were planted in the field no detectable differences in germination percentages were observed compared to the laboratory results (Alcantara et al., 1996). These results suggest that toxic level of EMS concentration and treatment exposure depends on the experimental conditions and on the variety used. In most of the characters, that is plant height, number of branches, days to flowering, number of fruits, length of the fruit, number of seeds per fruit and chlorophyll mutations the minimum variation was observed in control plants and the maximum variation were observed in the treated plants (Table 1.2 and Fig 1.5).

The observed variation in the treated population was more than that in the control population. This is the expected result because the control plant are suppose to be genetically similar and any kind of difference observed in the control plants is only due to environment. The results of the present study suggest that particular treatment time of the EMS below the toxic level (24hrs) can be used to increase in the genetic variability in Capsicum annuит L. which is the basis for any breeding program.
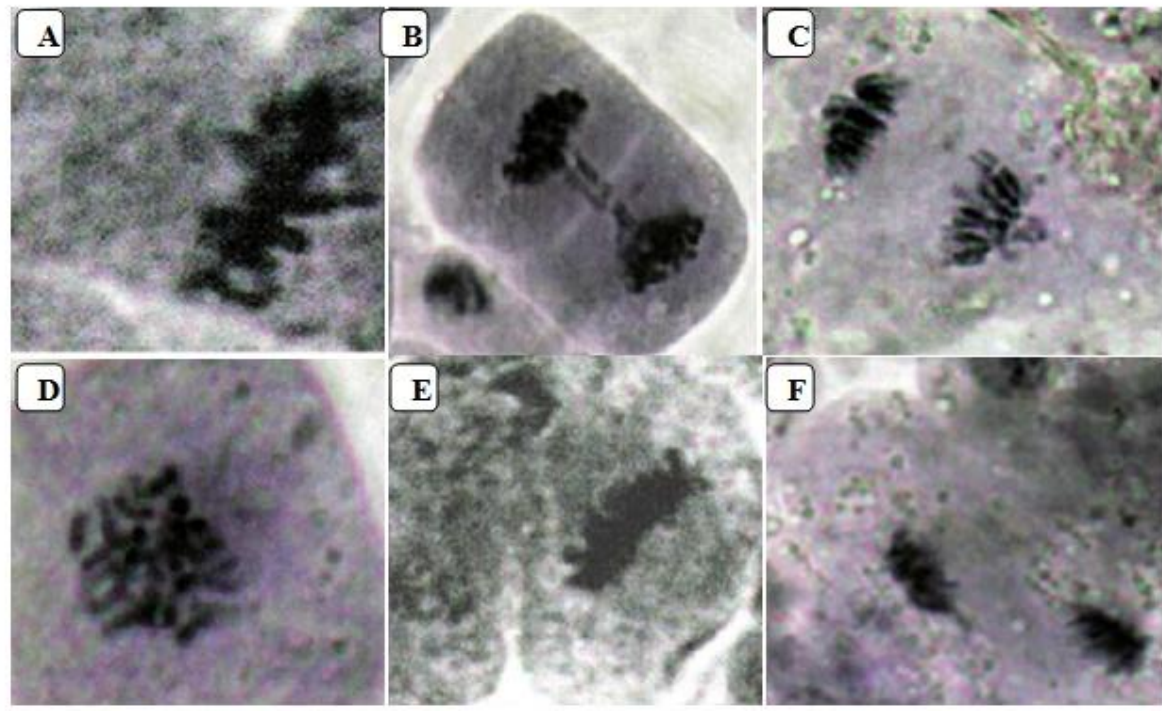

F

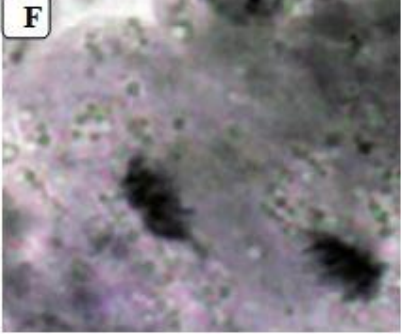

Fig. 1.5 A- Precocious stage of 6P7, B- double bridge structure in anaphase 24P41, C- anaphase of 6P39, Dprophase in control plant, E- sticky metaphase 24P86, F- non synchronized chromosomes in anaphase of 12P36. 


\section{Conclusion:-}

By our results we conclude that, using $0.1 \%$ EMS concentration for $6 \mathrm{hrs}$ can be used for induce morphological mutations. Several unique and interesting mutations were induced in this study. There were some mutants that were completely sterile and cannot be used for further studies. The fertile mutants generated in this study could be valuable for linkage and mapping studies of Capsicum annuиm L. Furthermore these mutants can also be used to isolate genes involved at different developmental stages of plants. Mutants isolated in this study as well as in many previous studies could serve as genetic markers. This reveals that mutation breeding is a valid and effective crop breeding method for short genome crops like Capsicum аппиит L.

Cytological studies revealed that the use of the use of chemical mutagens stimulated the mitotic activity in the roots of chilli, since the mitotic index increased with the increase in the treatment time. The mitotic index value increased up to a certain level treatment time. However, EMS treatments induced insignificant of mitotic abnormalities compared to control roots.

\section{Acknowledgement:-}

We duly thankful to Department of Biotechnology, Kakatiya Univesity, Warangal. We also sincerely, thank to Dr. CH.V. Purshotham Reddy, Chairmen of Chaitanya Colleges, to carry out my research in the college premises.

\section{References:-}

1. Anonymous, the British Pharmacopoeia. Published by the Stationary Office on Behalf of the Medicines and Health Care Products. Regulatory agency (MHRA) 2009;8: 1456-1460.

2. Alcantara, T.P, Bosland P.W. and Smith, D.W. Ethyl methane sulfonate induced mutagenesis of Capsicum annuum. J. Hered., 1996;87: 239-241.

3. Basu, S.K and De A.K. Capsicum: historical and botanical perspectives. In De AK (ed).The genus Capsicum. Taylor and Francis, London, 2003:1-15

4. Hajra, N.G. Induction of mutations by chemical mutagens in tall indica rice. Indian Agric., 1979; 23: 67-72.

5. Jabeen, $\mathrm{N}$ and Bushra, Mirza. Ethyl Methane Sulfonate Induces Morphological Mutations in Capsicum annuum. Int. J. Agri. Biol., 2004. 6; 340-345.

6. Leandro, P.E, Martin, TM and Jose, J.U. Constitutive expression of Arabidopsis Leafy or Apetala1 genes in citrus reduces their generation time. Nature., $2001: 263-5$

7. Lippert L.F, Bergh, B.O and Cook, A.A. Three variegated seedling mutants in the pepper. J. Hered., 1964; 55: 78-93.

8. Miller, P.D, Vaughn, K.C and Wilson, K.G. Ethyl methane sulfonate induced chloroplast mutagenesis in crops. J. Hered., 1984; 75: 86-92

9. Minocha, J.L and Arnason, T.J. Mutagenic effectiveness of ethyl methane sulfonate in barley. Nature., 1962; 196: 499-499.

10. Odeigah, P.G.C, Osanyinpeju A.O and Myers, G.O. Induced male sterility in cowpea (Vigna unguiculata L. Walp). J. Genet. Breed., 1996; 50: 171-176

11. Sebastian, S.A, Fader, G.M, Unlrich, J.F, Forney, D.R and Chaleff, R.S. Semidominant Soybean mutations for resistance to Sulfonyl Urea herbicides. Crop Sci., 1989; 24: 851-2.

12. Thurling, N and Depittayanan, V. EMS induction of early flowering mutants in springrape (Brassica napus). Pl. Breed., 1992; 108: 177-184. 